\title{
PENGARUH KOMPETENSI AKUNTANSI TERHADAP KETERAMPILAN BERPIKIR KRITIS MAHASISWA
}

\author{
Pujiati \\ Dosen FKIP Universitas Lampung \\ email:pujiati78@yahoo.com
}

\begin{abstract}
ABSTRAK
Penelitian ini bertujuan untuk mempelajari, mengukur, dan menganalisis pengaruh kompetensi akademik terhadap keterampilan berpikir kritis mahasiswa. Pendekatan yang digunakan adalah kuantitatif deskriptif dengan analisis korelasional. Sampel penelitian sebanyak 315 responden mencakup mahasiswa program studi Pendidikan Ekonomi dari tiga LPTK yaitu Fakultas Keguruan dan Ilmu Pendidikan Universitas Lampung, Fakultas Keguruan dan Ilmu Pendidikan Universitas Muhammadiyah Metro, dan STKIP PGRI Bandar Lampung. Kesimpulan dari penelitian ini adalah kompetensi akuntansi berpengaruh terhadap keterampilan berpikir kritis mahasiswa. Implikasi dari hasil penelitian bahwa keterampilan berpikir kritis dapat ditingkatkan dengan meningkatkan kompetensi akuntansi.
\end{abstract}

Kata Kunci: kompetensi akuntansi, keterampilan berpikir kritis

\begin{abstract}
This research aims to study, measure, and analyze the effect of academic competence on students' critical thinking skills. The approach used is quantitative descriptive correlational analysis. The research sample includes respondents as many as 315 students of Economic Education from three LPTKs, that is, the University of Lampung of teacher training and education faculty, Teacher training and education faculty, University of Muhammadiyah Metro, and STKIP PGRI Bandar Lampung. The conclusion of this study is the effect on the competence of accounting students' critical thinking skills. The implications of the findings that critical thinking skills can be improved by accounting competence.
\end{abstract}

Keywords: accounting competency, critical thinking skills

\section{PENDAHULUAN}

Keberhasilan pembangunan suatu bangsa ditentukan oleh kualitas sumber daya manusia. Tidak dapat dipungkiri untuk mencapai sumber daya manusia yang berkualitas, diperlukan pula pendidikan yang berkualitas. Melalui pendidikan yang berkualitas seseorang akan mendapatkan bekal pengetahuan, pemahaman dan keterampilan serta banyak contoh praktik bagaimana bersikap dan berperilaku baik yang kelak akan semakin mudah bagi seseorang tersebut untuk mendapatkan pekerjaan dan penghasilan sehingga dapat dicapai kesejahteraan hidup yang lebih baik. Dengan tercapainya pekerjaan dan penghasilan yang baik oleh setiap warga negara maka dapat dikatakan masyarakat sejahtera pun tercapai. Sumber daya manusia yang berkualitas, dan berpotensi amat diperlukan dalam mewujudkan kehidupan yang lebih baik, dan berpartisipasi secara aktif dalam pembangunan.

Peningkatan mutu pendidikan merupakan salah satu isu dari sekian banyak isu-isu kontroversial yang ada di negara kita. Mutu pendidikan menjadi masalah nasional dan perlu mendapat perhatian yang sungguhsungguh oleh seluruh elemen bangsa. Untuk meningkatkan mutu pendidikan di Indonesia, pemerintah telah banyak mengambil langkahlangkah, diantaranya peningkatan kompetensi tenaga pendidik dan kependidikan, melalui sertifikasi guru, berbagai latihan dan pendidikan, serta perbaikan kurikulum yang diharapkan dapat memberikan peluang yang lebih besar bagi peserta didik untuk memperoleh pendidikan sesuai dengan 
minat, bakat dan kemampuannya.

Keterampilan berpikir kritis merupakan salah satu keterampilan yang dibutuhkan di era globalisasi dimana pada era ini terdapat perubahan yang begitu cepat dan kompetisi yang ketat. Keterampilan berpikir sejalan dengan wacana meningkatkan mutu pendidikan malalui proses pembelajaran yang sesuai dengan tuntutan tujuan atau hasil belajar (Kuswana, 2011:23). Pembelajaran berpikir merupakan dasar untuk membangun pengetahuan, sikap, dan keterampilan motorik dalam pencapaian kompetensi secara utuh, sesuai dengan mata pelajaran atau keahlian tertentu (Kuswana, 2011: iii).

Fenomena rendahnya keterampilan berpikir kritis nampak di masyarakat. Hal ini dapat diketahui dari semakin banyaknya sikap dan perilaku yang tidak menunjukkan indikasi berpikir kritis. Diantaranya adalah kenyataan yang dilihat dalam keseharian semakin banyak masyarakat yang jauh dari berpikir logis dan rasional, lebih mengutamakan jalan pintas tanpa mempertimbangkan akibat di kemudian hari baik bagi dirinya sendiri maupun bagi orang lain.Tilaar (2012:93) menyatakan "Gelombang globalisasi yang telah menghapuskan batas-batas ruang ditopang oleh teknologi informasi yang menghancurkan batas-batas waktu, telah mengubah tata pergaulan umat manusia". Terkait dengan hal tersebut, diperlukan bekal yang cukup untuk dapat survive menghadapi tantangan yang ada di era globalisasi ini. Sejumlah bekal yang harus melekat erat dalam diri seseorang diantaranya adalah skills (keterampilan). Salah satu skills (keterampilan) yang bermanfaat dalam kehidupan di era globalisasi adalah berpikir kritis.

Seseorang yang memiliki keterampilan berpikir kritis akan mendapat banyak manfaat baik dalam lingkup kelas (pembelajaran di sekolah), dalam dunia kerja, maupun dalam hidup bermasyarakat. Bassham et al.
(2008:29) menjelaskan bahwa:

Critical thinking is beneficial for many reasons. It can help students do better in school by improving their ability to understand, construct, and criticize arguments. It can help people succed in their careers by improving their ability to solve problems, think creatively, and communicate their ideas clearly and effectively. It can also reduce the likehood of making serious mistakes in important personal decisions, promote democratic processes by improving the quality of public decision making, and liberate and empower individuals by freeing them from the unexamined assumptions, dogmas, and prejudices of their upbringing, their society, and their age.

Berdasarkan pendapat tersebut, diketahui bahwa berpikir kritis amat berguna dalam meningkatkan kemampuan dalam memahami, mengkonstruksi dan mengambil keputusan serta membebaskan seseorang dari dogma dan prasangka. Pendapat tersebut menegaskan pentingnya keterampilan berpikir kritis pada diri seseorang dengan kehidupan di masa yang akan datang.

Perguruan tinggi sebagai salah satu institusi yang menghasilkan output sumberdaya manusia yang berpendidikan memiliki peran yang strategis. Segenap civitas akademika yang ada di dalamnya merupakan agent of change dalam masyarakat. Melalui fasilitas dan sumber daya yang ada, perguruan tinggi akan mampu berkontribusi dalam dinamika perkembangan masyarakat yang sangat kompleks khususnya di era globalisasi.

Berdasarkan studi pendahuluan dan observasi pada proses pembelajaran yang telah berlangsung selama ini, diketahui bahwa keterampilan berpikir kritis mahasiswa di perguruan tinggi belum optimal. Secara umum diketahui bahwa rata-rata perolehan Indeks Prestasi Mahasiswa sudah mampu mencapai $>3,00$ adalah lebih dari $65 \%$, 
akan tetapi ditinjau dari aspek keterampilan berpikir kritis baru mencapai kisaran 40\%$50 \%$ (hasil observasi pembelajaran dan wawancara dengan beberapa dosen di program studi Pendidikan Ekonomi Fakultas keguruan dan Ilmu Pendidikan Universitas Lampung, Universitas Muhammadiyah Metro dan STKIP PGRI Bandar Lampung).

Akuntansi merupakan salah satu bidang ilmu yang tidak cukup dipelajari dari sisi teori saja, tetapi, akuntansi lebih mudah dimengerti dengan praktik akuntansi secara nyata. Akuntansi memberikan pengetahuan dan keterampilan kepada mahasiswa tentang satu siklus kegiatan akuntansi dalam suatu perusahaan baik secara manual maupun dengan menggunakan program software tertentu. Dalam akuntansi, mahasiswa dibekali beragam pengetahuan dan keterampilan yang menuntut proses berpikir tingkat tinggi (high order thinking). Salah satu aspek berpikir tingkat tinggi yang dipelajari dalam akuntansi adalah berpikir kritis. National Council for Excellence in Critical Thinking (1987) sebagaimana dikutip Tuanakotta (2011: 9-10) menyatakan: "Berpikir kritis adalah proses intelektual berdisiplin yang secara aktif dan cerdas mengkonseptualisasikan, menerapkan, menganalisis, mensintesekan, dan/atau mengevaluasi informasi yang dikumpulkan, atau dihasilkan melalui observasi, pengalaman, refleksi (perenungan kembali), nalar, atau komunikasi sebagai panduan mengenai apa yang dipercaya dan tindakan yang diambil. Berpikir kritis didasarkan atas nilai intelektual universal yang melampaui uraian pokok persoalan ke dalam kejelasan, ketepatan, akurasi, presisi, konsistensi, relevan, bukti yang memadai, nalar yang baik, kedalaman, luas dan fairness." Sedangkan dimensi berpikir kritis menurut Rubenfeld dan Scheffer (2006:22-23) ada 17 yaitu: (1) menganalisis, (2) menerapkan standar, (3) mendiskriminasi, (4) mencari informasi, (5) membuat alasan logis, (6) memprediksikan,
(7) mentransformasikan pengetahuan, (8) percaya diri, (9) perspektif kontekstual, (10) fleksibilitas, (11) kreativitas, (12) rasa ingin tahu, (13) integritas intelektual, (14) intuisi, (15) berpikiran terbuka, (16) tekun, dan (17) refleksi.

Aspek-aspek berpikir kritis sebagaimana tertulis tersebut merupakan aspek-aspek yang sangat esensial dan merupakan bagian dari kompetensi akuntansi. Dalam akuntansi ditunjukkan pula saling hubungan antar bagian akuntansi dengan bagian-bagian lain dalam perusahaan. Selanjutnya, mahasiswa dilatih untuk melakukan pencatatan mulai dari dokumen dasar (bukti transaksi) sampai dengan penyusunan laporan keuangan. Diduga bahwa semakin baik kompetensi akuntansi mahasiswa, maka keterampilan berpikir kritisnya pun akan semakin tinggi.

\section{METODE PENELITIAN}

Penelitian inimerupakan penelitian kuantitatif deskriptif dengan pendekatan korelasional yaitu suatu penelitian yang sering digunakan yang bertujuan menetapkan besarnya hubungan antara variabel-variabel. Studi korelasi memungkinkan peneliti memastikan sejauhmana perbedaan di salah satu variabel ada hubungannya dengan perbedaan dalam variabel yang lain. Besarnya hubungan itu ditetapkan dengan koefisien korelasi. (Ary, Jacobs and Razavieh, 1982:415)

Penelitian dilaksanakan di Bandar Lampung, melibatkan 3 (tiga) LPTK yang memiliki program studi Pendidikan Ekonomi terakreditasi yaitu FKIP Universitas Lampung, FKIP Universitas Muhammadiyah Metro dan STKIP PGRI Bandar Lampung. Pemilihan lokasi penelitian didasarkan pada: (1) Keterwakilan LPTK negeri dan swasta, (2) Ketersediaan program studi pada populasi sasaran, (3) Usia program studi, (4) Jumlah mahasiswa, dan (5) Status program studi.

Populasi dalam penelitian ini adalah seluruh mahasiswa program studi Pendidikan Ekonomi di FKIP Universitas Lampung, FKIP Universitas Muhammadiyah Metro dan 
STKIP PGRI Bandar Lampung yang sedang dan telah menempuh mata kuliah yang berkaitan dengan akuntansi yaitu mahasiswa dari angkatan 2007 sampai dengan 2011 berjumlah 1.496 orang.

Populasi Penelitian

\begin{tabular}{ccccc}
\hline & \multicolumn{3}{c}{ Perguruan Tinggi (LPTK) } & \\
\cline { 2 - 4 } Tahun Angkatan & $\begin{array}{c}\text { Jumlah Mahasiswa } \\
\text { Pendidikan Ekonomi } \\
\text { FKIP Unila }\end{array}$ & $\begin{array}{c}\text { Jumlah Mahasiswa } \\
\text { Pendidikan } \\
\text { Ekonomi FKIP } \\
\text { UMM }\end{array}$ & $\begin{array}{c}\text { Jumlah Mahasiswa } \\
\text { Pendidikan } \\
\text { Ekonomi STKIP } \\
\text { PGRI B. Lampung }\end{array}$ & Total \\
\hline 2007 & 10 & 3 & 7 & 20 \\
\hline 2008 & 49 & 126 & 148 & 323 \\
\hline 2009 & 90 & 204 & 155 & 449 \\
\hline 2010 & 87 & 195 & 136 & 418 \\
\hline 2011 & 76 & 95 & 115 & 286 \\
\hline Total & 312 & 623 & 561 & 1496 \\
\hline
\end{tabular}

Sumber: Dokumentasi FKIP Unila, FKIP UMM, dan STKIP PGRI Bandar Lampung

Untuk menentukan jumlah sampel yang akan diteliti, digunakan rumus T. Yamane, yaitu:

Keterangan:

$$
n=\frac{N}{d J^{2}+1}
$$

$\mathrm{n}=$ Jumlah sampel

$\mathrm{N}=$ Jumlah populasi

$\mathrm{d}^{2}=$ Presisi (Riduwan, 2009: 18)

Berdasarkan rumus tersebut, apabila sampel error sebesar 5\%, maka besarnya sampel dalam penelitian ini adalah:

$$
\mathrm{n}=315 \quad n=\frac{1.496}{1.496(0, \boldsymbol{\theta})^{2}+1}
$$

Jadi, besarnya sampel dalam penelitian ini adalah 315 orang.

Banyaknya sampel yang akan diteliti ditentukan secara proportional random

\begin{tabular}{|c|c|c|c|c|c|c|c|}
\hline \multirow[b]{2}{*}{$\begin{array}{c}\text { Tahun } \\
\text { Angka-tan }\end{array}$} & \multirow[b]{2}{*}{$\begin{array}{c}\text { Jml } \\
\text { MhswPend. } \\
\text { Eko. FKIP } \\
\text { Unila }\end{array}$} & \multirow[b]{2}{*}{$\begin{array}{l}\text { Jml Mhsw } \\
\text { Pend. Eko. } \\
\text { FKIP UMM }\end{array}$} & \multirow[b]{2}{*}{$\begin{array}{l}\text { Jml MhswPend. } \\
\text { Eko. STKIP PGRI } \\
\text { B. Lpg }\end{array}$} & \multirow[b]{2}{*}{ Total } & \multicolumn{3}{|c|}{ Perhitungan Sampel } \\
\hline & & & & & $\begin{array}{c}\text { Mahasiswa } \\
\text { Pendidikan Ekonomi } \\
\text { FKIP } \\
\text { Unila }\end{array}$ & $\begin{array}{l}\text { Mahasiswa Pend. } \\
\text { Ekonomi FKIP } \\
\text { UMM }\end{array}$ & $\begin{array}{c}\text { Mahasiswa Pendidikan } \\
\text { Ekonomi STKIP PGRI } \\
\text { B. Lampung }\end{array}$ \\
\hline 2007 & 10 & 3 & 7 & 20 & $10 / 1.496 \times 315=2$ & $3 / 1.496 \times 315=1$ & $7 / 1.496 \times 315=2$ \\
\hline 2008 & 49 & 126 & 148 & 323 & $49 / 1.496 \times 315=10$ & $126 / 1.496 \times 315=26$ & $148 / 1.496 \times 315=31$ \\
\hline 2009 & 90 & 204 & 155 & 449 & $90 / 1.496 \times 315=19$ & $204 / 1.496 \times 315=43$ & $155 / 1.496 \times 315=33$ \\
\hline 2010 & 87 & 195 & 136 & 418 & $87 / 1.496 \times 315=18$ & $195 / 1.496 \times 315=41$ & $136 / 1.496 \times 315=29$ \\
\hline 2011 & 76 & 95 & 115 & 286 & $76 / 1496 \times 315=16$ & $95 / 1.496 \times 315=20$ & $115 / 1.496 \times 315=24$ \\
\hline Total & 312 & 623 & 561 & 1496 & 65 & 131 & 119 \\
\hline
\end{tabular}
sampling sebagai berikut:

Perhitungan Sampel

Berdasarkan perhitungan tabel tersebut diketahui bahwa jumlah sampel untuk masing-masing Lembaga Pendidikan Tenaga Kependidikan (LPTK) yaitu mahasiswa Pendidikan Ekonomi FKIP Universitas Lampung 65 orang, mahasiswa Pendidikan Ekonomi FKIP Universitas Muhammadiyah Metro berjumlah 131 orang dan mahasiswa Pendidikan Ekonomi STKIP PGRI Bandar Lampung sebanyak 119 orang, dengan rincian per angkatan sebagaimana tertera dalam tabel di atas.

Instrumen keterampilan berpikir kritis dikembangkan/dimodifikasi oleh peneliti dengan mengacu kepada teori dan indikator instrumen yang sudah baku dari Rubbenfeld \& Scheffer (2006). Data keterampilan berpikir kritis dijaring melalui angket skala beda semantic yang terdiri dari sejumlah pernyataan positif dan negatif dengan sepuluh opsi jawaban yaitu dengan rentang skala dari sangat tidak setuju hingga sangat setuju. 
Skoring opsi jawaban untuk ítem negatif adalah berkebalikan dengan ítem positif. Format Item dan Penskoran Instrumen Angket sebagai berikut:

Item Positif $=$

$\begin{array}{llllll}\text { Sangat tidak setuju } & 1 & 2 & 3 & 4 & 5\end{array}$

$\begin{array}{llllll}6 & 7 & 8 & 9 & 10 & \text { Sangat setuju }\end{array}$

Item negatif $=$

Sangat tidak setuju $10 \quad 9 \quad 8 \quad 7 \quad 6$ $\begin{array}{llllll}5 & 4 & 3 & 2 & 1 & \text { Sangat setuju }\end{array}$
Sementaraitu, untukinstrumen tes kompetensi akuntansi diadaptasi dari instrumen yang dikembangkan oleh Pujiati (2006) dalam tesisnya yang berjudul "Pengembangan Praktik Akuntansi Untuk Mahasiswa Jurusan Akuntansi". Tes kompetensi akuntansi meliputi analisis bukti-bukti transaksi keuangan, mencatat hasil analisis buktibukti transaksi ke dalam jurnal umum, jurnal khusus dan buku besar pembantu, memposting jurnal ke dalam buku besar

Tabel Pedoman Penskoran Test Kompetensi Akuntansi

\begin{tabular}{clc}
\hline No. & \multicolumn{1}{c}{ Aspek yang Dinilai } & Skor \\
\hline 1. & Analisis bukti-bukti transaksi keuangan & 10 \\
\hline 2. & Mencatat hasil analisis bukti-bukti transaksi ke dalam jurnal umum & 5 \\
\hline 3. & Mencatat hasil analisis bukti-bukti transaksi ke dalam jurnal khusus & 5 \\
\hline 4. & Mencatat hasil analisis bukti-bukti transaksi ke dalam buku besar pembantu & 5 \\
\hline 5. & Memposting jurnal ke dalam buku besar umum & 5 \\
\hline 6. & Menyusun neraca saldo & 5 \\
\hline 7. & Membuat ayat jurnal penyesuaian & 5 \\
\hline 8. & Memposting ayat jurnal penyesuaian ke dalam buku besar & 5 \\
\hline 9. & Menyusun kertas kerja & 10 \\
\hline 10. & Membuat ayat jurnal penutup & 5 \\
\hline 11. & Memposting ayat jurnal penutup ke dalam buku besar & 5 \\
\hline 12. & Menyusun neraca saldo setelah penutupan & 5 \\
\hline 13. & Membuat ayat jurnal pembalik & 5 \\
\hline 14. & Menyusun laporan keuangan & 20 \\
\hline 15. & Membuat perhitungan harga pokok penjualan & 5 \\
\hline & Total Skor Maksimal & 100 \\
\hline
\end{tabular}

umum, menyususn neraca saldo, membuat ayat jurnal penyesuaian, memposting ayat jurnal penyesuaian ke dalam buku besar, menyususn kertas kerja, membuat ayat jurnal penutup, memposting ayat jurnal penutup ke dalam buku besar, menyusun neraca saldo setelah penutupan, membuat ayat jurnal pembalik, menyusun laporan keuangan, dan membuat perhitungan harga pokok penjualan. Skor minimum tes kompetensi adalah 0 dan skor maksimal 100. Berikut tabel pedoman penskoran dari tes kompetensi akuntansi:

Sebelum instrumen digunakan terlebih dahulu diujicobakan untuk mengetahui tingkat validitas dan reliabilitasnya. Adapun hasil uji reliabilitas untuk instrumen kompetensi akuntansi adalah sebesar 0,970 dan keterampilan berpikir kritis sebesar 0,888 . Sedangkan uji validitas menunjukkan hasil keseluruhan instrumen valid. Berdasarkan hasil perhitungan anates menunjukkan bahwa instrumen tes kompetensi akuntansi pada tiap sub materi adalah cukup, baik dan sangat baik sehingga dapat dikatakan bahwa instrumen tes kompetensi akuntansi mampu membedakan kelompok mahasiswa berkemampuan tinggi, sedang, maupun rendah. Data penelitian dianalisis dengan bantuan perangkat lunak SPSS menggunakan analisis regresi dan korelasi. 
HASIL DAN PEMBAHASAN

Deskripsi Data

Data Kompetensi Akuntansi (X4)
Berdasarkan angket yang telah diisi oleh 315 responden diperoleh data sebagai berikut:

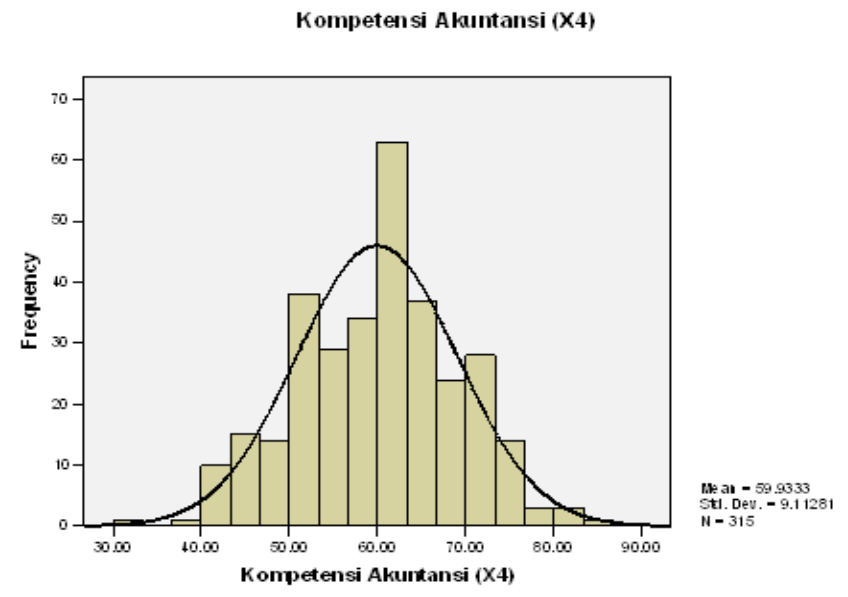

Grafik

Histogram Kompetensi akuntansi

Berdasarkan histogram di atas dapat dilihat bahwa perolehan skor minimal adalah 30, skor maksimal 89, rata-rata kompetensi akuntansi adalah 59,9333 dengan standar deviasi
9,11281. Sementara itu, jika dikategorikan ke dalam tiga kategori (tinggi, sedang dan rendah), maka sebaran data kompetensi akuntansi dapat dilihat pada table dan grafik berikut ini:

Kompetensi Akuntansi dalam Tiga Kategori

\begin{tabular}{ccccc}
\hline No & & Kategori & f & $\%$ \\
\hline 1 & Tinggi & & 62 & 19,7 \\
\hline 2 & Sedang & & 218 & 69,2 \\
\hline 3 & Rendah & & 35 & 11,1 \\
\hline & & Jumlah & 315 & 100 \\
\hline
\end{tabular}

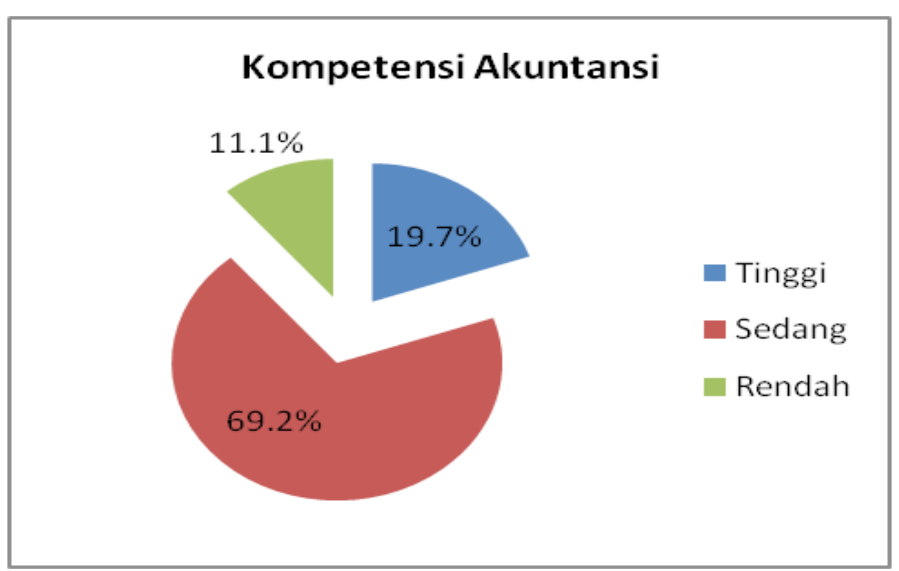

Grafik

Kompetensi Akuntansi dalam Tiga Kategori

Tabel dan grafik tersebut menggambarkan mengenai "kompetensi akuntansi". Dari 315 orang yang diteliti, 62 orang (19,7\%) menilai kompetensi akuntansi dengan kategori tinggi,
218 orang $(69,2 \%)$ menilai kompetensi akuntansi dengan kategori sedang dan 35 orang $(11,1 \%)$ menilai kompetensi akuntansi dengan kategori rendah. Hal ini menunjukkan 
bahwa sebagian besar dari responden menilai kompetensi akuntansi dengan kategori sedang.

\section{Data Keterampilan Berpikir Kritis Mahasiswa (Y)}

Berdasarkan angket yang telah diisi oleh 315 responden diperoleh data sebagai berikut:

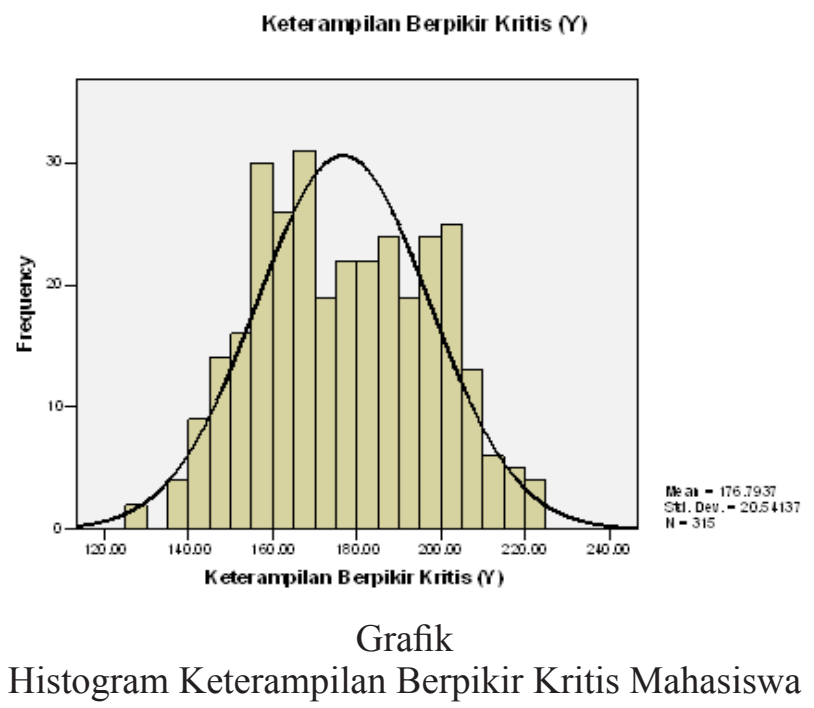

Berdasarkan histogram tersebut dapat dilihat bahwa perolehan skor minimal sebesar 128 , skor maksimal 227, rata-rata 176,7937 dengan nilai standar deviasi 20,54137. Sementara itu, jika dikategorikan ke dalam tiga kategori (tinggi, sedang dan rendah), maka sebaran data keterampilan berpikir kritis mahasiswa dapat dilihat pada table dan grafik berikut ini:

Tabel

Keterampilan Berpikir Kritis dalam Tiga Kategori

\begin{tabular}{ccccc}
\hline No & & Kategori & $f$ & $\%$ \\
\hline 1 & Tinggi & & 84 & 26,7 \\
\hline 2 & Sedang & & 150 & 47,6 \\
\hline 3 & Rendah & & 81 & 25,7 \\
\hline & & Jumlah & 315 & 100 \\
\hline
\end{tabular}

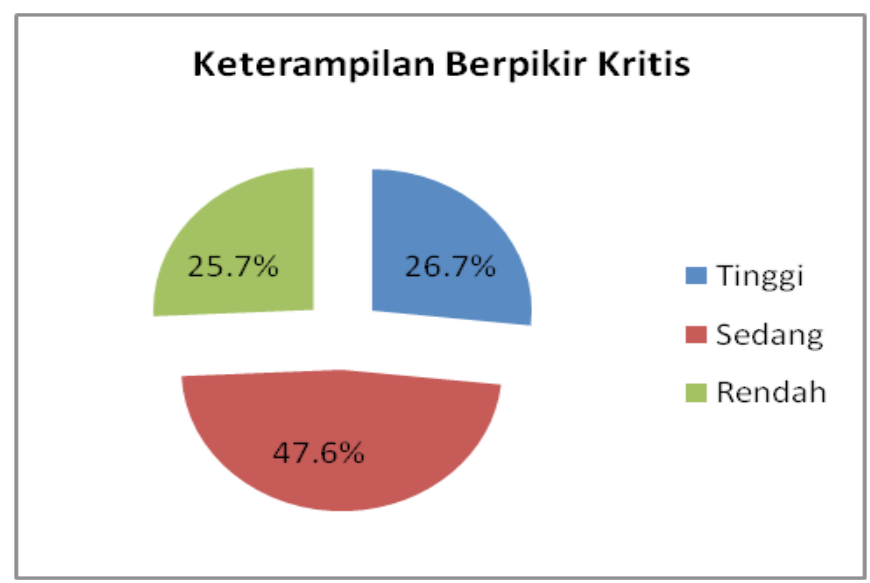

Grafik

Keterampilan Berpikir Kritis dalam Tiga Kategori

Tabel dan grafik tersebut menggambarkan mengenai "keterampilan berpikir kritis mahasiswa". Dari 315 orang yang diteliti, 84 orang $(26,7 \%)$ menilai keterampilan berpikir kritis dengan kategori tinggi, 150 orang $(47,6 \%)$ menilai keterampilan berpikir kritis dengan kategori sedang dan 81 orang $(25,7 \%)$ menilai keterampilan berpikir kritis 
dengan kategori rendah. Hal ini menunjukkan bahwa sebagian besar dari responden menilai keterampilan berpikir kritis dengan kategori sedang.

\section{Pengujian Hipotesis:}

Hipotesisnya berbunyi:

H0: $\rho_{\mathrm{y}} \mathrm{X}_{4}=0$ Kompetensi akuntansi tidak berpengaruh positif terhadap

keterampilan berpikir kritis mahasiswa

Ha: $\rho_{\mathrm{y}} \mathrm{X}_{4}>0$ Kompetensi akuntansi berpengaruh positif terhadap keterampilan berpikir kritis mahasiswa

Berdasarkan hasil perhitungan, diperoleh angka $\mathrm{t}$ penelitian sebesar $6,182>\mathrm{t}$ table sebesar 1,65. Oleh karena itu, H0 ditolak dan $\mathrm{Ha}$ diterima. Artinya, ada pengaruh linier antara kompetensi akuntansi terhadap keterampilan berpikir kritis mahasiswa. Besarnya pengaruh kompetensi akuntansi terhadap keterampilan berpikir kritis mahasiswa sebesar 0,271 atau 27,1\%.

Berdasarkan perhitungan diperoleh angka korelasi antara variabel kompetensi akuntansi dengan keterampilan berpikir kritis mahasiswa sebesar 0,484. Korelasi sebesar 0,484 mempunyai maksud hubungan antara variabel kompetensi akuntansi dengan keterampilan berpikir kritis kuat dan searah (karena hasilnya positif). Searah artinya jika kompetensi akuntansi baik/tinggi, maka keterampilan berpikir kritis mahasiswa juga baik/tinggi. Korelasi dua variabel bersifat signifikan karena angka signifikansi sebesar $0,000<0,01$. Jika angka signifikansi (sig) $<0,01$, maka hubungan kedua variabel signifikan. Sebaliknya, jika angka signifikansi (sig) $>0,01$, maka hubungan kedua variabel tidak signifikan. Angka 0,01 digunakan karena hasil perhitungan SPSS memberikan angka signifikansi sebesar 0,01 yang ditandai dengan dua bintang (**). Standar SPSS berada di antara 0,01 sampai 0,05.

Hasil pengujian hipotesis menunjukkan bahwa kompetensi akuntansi berpengaruh positif terhadap keterampilan berpikir kritis mahasiswa. Ini mengandung arti bahwa semakin tinggi kompetensi akuntansi akan semakin meningkatkan keterampilan berpikir kritis mahasiswa. Hal ini mengandung implikasi bahwa untuk meningkatkan keterampilan berpikir kritis mahasiswa dapat dilakukan dengan meningkatkan kompetensi akuntansi.

Hasil penelitian ini sejalan dengan pendapat Eggen dan Kauchak (2012:115) yang menyatakan berpikir kritis adalah kemampuan dan kecenderungan seseorang untuk membuat dan melakukan asesmen terhadap kesimpulan berdasarkan bukti. Membuat dan melakukan asesmen terhadap kesimpulan berdasarkan bukti tidaklah sederhana. Eggen dan Kauchak (2012:115) menjelaskan ada beberapa contoh proses tindak lanjut yang melibatkan penggunaan bukti yaitu: 1) mengidentifikasi asumsiasumsi tersirat, 2) mengenali generalisasi berlebihan dan kurangnya generalisasi, 3) mengidentifikasi informasi yang relevan dan tidak relevan, dan 4) mengidentifikasi bias, strreotipe, klise dan propaganda. Kompetensi akuntansi sarat dengan proses berbasis bukti-bukti transaksi keuangan. Melalui kompetensi akuntansi dapat dioptimalkan keterampilan berpikir peserta didik. Proses tindak lanjut yang dikemukakan oleh Eggen dan Kauchak tersebut dapat diintegrasikan dalam pembelajaran sehingga kecenderungan peserta didik untuk berpikir kritis dapat ditumbuhkembangakan. Alhasil dengan meningkatnya kompetensi akuntansi peserta didik semakin meningkat pula keterampilan berpikir kritisnya.

Akuntansi menyajikan informasi yang bersifat keuangan. Pengembangan akuntansi berlandaskan pada 3 (tiga) pilar utama, yaitu matematika, prinsip-prinsip dasar, dan rancang-bangun. Pilar matematika menjaga keseimbangan antara total penggunaan dana dan total pemerolehan dana. Pilar prinsipprinsip dasar menjadikan pengembangan 
akuntansi lebih terarah. Selanjutnya, rancang bangun menjadikan akuntansi dapat menyajikan informasi keuangan sesuai kebutuhan para pengguna (Warsono et al. 2009:1). Keterampilan berpikir kritis dapat ditingkatkan melalui peningkatan kompetensi akuntansi. Semakin tinggi kompetensi akuntansi seseorang maka keterampilan berpikir kritisnya pun akan tinggi. Carol dalam Eggen dan Kauchak (2012: 114-115) menjelaskan berpikir kritis memiliki tiga ciri penting, Pertama fakta bahwa dia menuntut siswanya untuk memberikan bukti bagi kesimpulan mereka yang memungkinkan para siswa mempraktikkan berpikir kritis di dalam kegiatan belajar bahasa yang sederhana. Kedua, kegiatannya menggambarkan kesalingtergantungan antara berpikir dan belajar. Ketiga, menekankan berpikir kritis nyaris tidak membutuhkan upaya apapun melainkan bertanya, terus waspada terhadap peluang untuk mengajukan pertanyaanpertanyaan. Berdasarkan pendapat tersebut dapat dikatakan bahwa pada proses pembelajaran akuntansi terjadi proses pembelajaran berpikir kritis. Peserta didik diajak untuk mengoptimalkan keterampilan berpikir kritis melalui bukti-bukti transaksi.

Sebagaimana dijelaskan Eggen dan Kauchak (2012:115) di atas bahwa bepikir kritis merupakan kemampuan dan kecenderungan untuk membuat dan melakukan asesmen terhadap kesimpulan berdasarkan bukti. Kecenderungan merupakan aspek terpenting dari berpikir secara kritis. Kecenderungan untuk menggunakan bukti. Kecenderungankecenderungan ini berkembang seiring waktu pemodelan dan penerapannya. Peluang untuk mendorong dan memotivasi kecenderungankecenderungan ini terjadi secara sering dalam ruang kelas. Sikap dan kecenderungan yang terkait dengan berpikir kritis yaitu: hasrat untuk mendapatkan informasi dan mencari bukti, sikap berpikiran terbuka dan skeptisisme sehat, kecenderungan untuk menunda penghakiman, rasa hormat terhadap pendapat orang lain, dan toleransi bagi ambiguitas (Eggen dan Kauchak, 2012: 119).

Akuntansi merupakan proses sistematik untuk mengolah transaksi menjadi informasi keuangan yang bermanfaat bagi para penggunanya. Akuntansi terdiri dari 3 (tiga) komponen utama, yaitu:

1) Input (masukan); berupa transaksi, yaitu peristiwa bisnis yang bersifat keuangan.

2) Proses (prosedur); meliputi berbagai fungsi mulai dari pengidentifikasian transaksi sampai dengan penyajian informasi keuangan. Proses utama akuntansi adalah pencatatan yang terdiri dari 2 (dua) fungsi, ayitu penjurnalan dan pemindah-bukuan.

3) Output (keluaran); berupa informasi keuangan. Salah satu output akuntansi yang benyak dikenal adalah laporan keuangan (financial statement) yang terdiri dari laporan laba/rugi, laporan perubahan ekuitas, neraca, dan laporan arus kas. (Warsono et al., 2009:3)

Dikarenakan akuntansi memiliki proses yang sistematik, maka Eggen dan Kauchak (2012:120) menjelaskan bahwa membantu peserta didik mengembangkan kemampuan berpikir kritis mereka adalah hal yang sukar karena orang tidak memiliki kecenderungan untuk berpikir kritis. Pendidik dapat mendorong pemikiran kritis di dalam ruang kelas mereka dengan mengajukan pertanyaanpertanyaan seperti "bagaimana kalian tahu?" dan "Mengapa kalian mengatakan itu?" pertanyaan-pertanyaan ini bias diintegrasikan degan mudah ke dalam kegiatan belajar. Membelajarkan berpikir juga dapat meningkatkan motivasi peserta didik karena memberikan bukti akan membantu peserta didik merasa cakap dan pintar.

Kompetensi Akuntansi merupakan salah satu bentuk dari aktivitas-aktivitas otentik yang dapat mendorong seseorang berpikir kritis. Aktivitas-aktivitas otentik dalam akuntansi mencakup praktik akuntansi yang di dalamnya 
terdapat sifat-sifat baik (virtue) yang oleh Belkaoui dan Riahi (2006:54) diuraikan sebagai berikut: "kejujuran, memiliki kepedulian terhadap status ekonomi pihak lain, sensitif terhadap nilai kerjasama dan konflik, sifat akuntansi yang komunikatif, serta penyebaran informasi ekonomi”.

Kompetensi akuntansi tersebut berisi tugastugas dan praktik yang menantang untuk berpikir kritis. Hal ini diperkuat melalui salah satu asumsi dasar Vigotsky yang menyatakan bahwa "tugas-tugas yang menantang akan mendorong pertumbuhan kognitif yang maksimum. Zona perkembangan proksimal setiap anak secara alamiah berkembang seiring waktu: saat sejumlah tugas telah dikuasai anak, tugas-tugas yang lebih rumit akan menggantikan tugas-tugas yang telah dikuasai tersebut". (Ormrod, 2008:58-59)

Kompetensi akuntansi meliputi pengetahuan dan keterampilan akuntansi. Dalam pembelajaran akuntansi senantiasa berbasis praktik. Praktik akuntansi didasarkan pada bukti-bukti transaksi keuangan yang kemudian diidentifikasi, diikhtisarkan untuk selanjutnya dilaporkan dalam bentuk laporan keuangan. Hasil penelitian ini mendukung teori Rubenfeld dan Scheffer (2006:212) yang menjabarkan bahwa:

"Dengan praktik berbasis bukti, seseorang harus memutuskan kapan waktunya harus mencari bukti (mendeskripsikan pertanyaan), apa yang terkandung dalam bukti, dimana dan bagaimana bukti tersebut dapat ditemukan, kualitas bukti tersebut, bagaimana cara terbaik menerjemahkan bukti ke dalam praktik, apa kemungkinan konsekuensi dari penggunaan pendekatan yang didukung oleh bukti, dan setelah menggunakannya, bagaimana menentukan apakah praktik berbasis bukti adalah tindakan "terbaik". Pernyataan tersebut menyiratkan penggunaan keterampilan berpikir kritis berupa menganalisis, menerapkan standar, mendeiskriminasi/membedakan, dan mencari informasi, memberikan alasan logis, memprediksikan, dan mentransformasikan pengetahuan.
Pernyataan tersebut juga menyiratkan kebiasaan pikiran seperti perspektif kontekstual, rasa ingin tahu, integritas intelektual, dan berpikiran terbuka.

Praktik berbasis bukti yang melekat pada kompetensi akuntansi merupakan penguat bagi tumbuhkembangnya keterampilan berpikir kritis mahasiswa. Rubenfeld dan Scheffer (2006:221) menuliskan keterkaitan antara berpikir kritis dengan praktik berbasis bukti mencakup:

"mengidentifikasi sebuah masalah atau area ketidakpastian, menanyakan pertanyaan yang relevan, terfokus, dan penting yang dapat dijawab, memilih sumber-sumber yang paling cenderung dicari,mencaridanmenghargaibuktiyang ditemukan, mengkaji pentingnya bukti, mengkaji bukti apakah dapat diterapkan, melaksanakan dan menerapkan bukti secara tepat, mengkaji hasil tindakan, merangkum dan menyimpan catatan untuk menjadi bahan referensi di masa depan".

Berdasarkan pemaparan di atas dapat diketahui bahwa semakin baik penguasaan kompetensi akuntansi akan semakin meningkatkan keterampilan berpikir kritis mahasiswa. Keterampilan berpikir kritis yang tinggi akan memperkuat karakter dan jati diri dan daya saing bangsa.

\section{KESIMPULAN}

Kompetensi akuntansi berpengaruh positif dan signifikan terhadap keterampilan berpikir kritis. Pengaruh positif dan signifikan ini berarti bahwa meningkatnya kompetensi akuntansi akan diikuti pula peningkatan pada variable keterampilan berpikir kritis. Ini mengandung arti bahwa semakin tinggi kompetensi akuntansi akan semakin meningkatkan keterampilan berpikir kritis mahasiswa. Hal ini mengandung implikasi bahwa untuk meningkatkan keterampilan berpikir kritis mahasiswa dapat dilakukan dengan meningkatkan kompetensi akuntansi. 


\section{DAFTAR PUSTAKA}

Bassham et al. 2008. Critical Thinking. A Student's Introduction. Third edition. New York: Mc Graw-Hill International.

Belkaoui dan Riahi, A. 2006. Accounting Theory. Jakarta: Salemba Empat.

Eggen, P. and Kauchak, D. 2012. Strategi dan Model Pembelajaran. Mengajarkan Konten dan Keterampilan Berpikir, Edisi 6. Jakarta: Indeks.

Kuswana, W. S. 2011. Taksonomi Berpikir. Bandung: Rosdakarya.

Ormrod, J. E. 2008. Psikologi Pendidikan. Membantu Siswa Tumbuh dan Berkembang. Edisi keenam. Jilid 1. Jakarta: Erlangga.

Ormrod, J. E. 2008. Psikologi Pendidikan. Membantu Siswa Tumbuh dan Berkembang. Edisi keenam. Jilid 2. Jakarta: Erlangga.

Pujiati. 2006. Pengembangan Bahan Ajar Praktikum Pengantar Akuntansi untuk Mahasiswa Jurusan Akuntansi. Tesis Tidak Diterbitkan. Lampung: Program Pascasarjana Universitas Lampung.

Rubenfeld, M. Gaie dan Scheffer, Barbara K. 2006. Critical Thinking Tactics for Nurses. Jones and barlett Publishers, Inc.

Tuanakotta, T. M. 2011. Berpikir Kritis dalam Auditing. Jakarta: Salemba Empat.

Warsono dan Hariyanto. 2012. Pembelajaran Aktif. Bandung: Rosda. 